\title{
PENGEMBANGAN E-MODUL GEOMETRI DENGAN PENDEKATAN MATEMATIKA REALISTIK DI SEKOLAH DASAR
}

\author{
Achmad Buchori \\ Noviana Dini Rahmawati \\ Program Studi Pendidikan Matematika Universitas PGRI Semarang \\ Jln Sidodadi Timur No 24 Semarang \\ e-mail:achmadbuchori@upgris.ac.id
}

\begin{abstract}
This study aims at developing 4D model into 3D following define, design, and development phase. E-module with RME approach is firstly validated by media expert, material expert and also questionnaire of student response. It obtained a score of $85.2 \%$ from a material expert, $89.2 \%$ from media expert validation $89.2 \%$, and $85.2 \%$ from students' response, hence, E-modules developed deserve to be utilized with the very good category. In addition, the experiment class' learning outcomes are better than control classes. Therefore, E-module development with RME approach is feasible and can be used in elementary mathematics learning particularly in Geometry learning.
\end{abstract}

Keywords: development, e-module, RME, elementary school

\begin{abstract}
Abstrak: Penelitian ini bertujuan untuk mengembangan model 4D menjadi 3D dengan tahap define (pendefinisian), design (perencanaan), dan development (pengembangan). E-modul dengan pendekatan PMR terlebih dahulu dilakukan uji validasi oleh ahli media, ahli materi dan juga angket tanggapan siswa. Diperoleh rata-rata penilaian validasi ahli materi $85,2 \%$, validasi ahli media $89,2 \%$, penilaian tanggapan siswa $85,2 \%$, Jadi media E-modul layak digunakan dengan kategori sangat baik. Hasil belajar kelas eksperimen lebih baik dari kelas kontrol. Jadi pengembangan E-modul dengan pendekatan PMR layak dan dapat digunakan dalam pembelajaran matematika SD khususnya geometri.
\end{abstract}

Kata Kunci: pengembangan, e-modul, PMR, Sekolah Dasar

Matematika merupakan salah satu mata pelajaran yang memegang peranan yang sangat penting dalam pendidikan. (Devi \& Ahmadi, 2014:52). Freudenthal (2002) berpendapat bahwa matematika merupakan aktivitas insani (human activities) dan harus dikaitkan dengan realitas. Menurut Wayan, dkk (2013:3) sistem pembelajaran yang didasarkan atas system teori-contoh-latihan ini hanya akan menyajikan suatu pandangan yang sempit tentang materi pembelajaran. Sebagaimana yang dijelaskan oleh Henvel-Panhuizen (1996:11), "bila anak belajar matematika terpisah dari pengalaman mereka sehari-hari, maka anak akan cepat lupa dan tidak dapat mengaplikasikan matematika".

Berdasarkan wawancara informal yang dilakukan peneliti dengan salah satu guru matematika SD Negeri Pedurungan Tengah 01 Semarang diperoleh informasi di dalam pembelajaran matematika pada materi geometri datar siswa sering mengalami kesulitan dalam memahami konsep segiempat dan dalam mengerjakan soal siswa masih salah dan bingung untuk menentukan apa yang diketahui dari soal. Akibatnya, dilihat dari hasil ulangan harian, kebanyakan siswa nilainya masih di bawah KKM. 
Hasil penelitian Dickinson \& Sue (2012) menunjukkan bahwa awalnya matematika di empat negara yaitu Netherlands, USA, United Kingdom dan Belanda memiliki persentasi yang rendah dan menurun secara signifikan pada tes matematika. Tetapi setelah dilakukannya penyebaran RME (Research Mathematics Education) dari keempat negara tersebut mengalami peningkatan yang signifikan di dalam pemecahan masalah tes matematika. Penggunaan bahan ajar juga diperlukan di dalam menunjang pembelajaran. Menurut Saglam (2011) penggunaan bahan ajar menjadikan proses belajar mengajar menjadi lebih mudah, efisien dan menjadikan siswa cepat di dalam menangkap materi pembelajaran.

Menurut Heuvel-Panhuizen (1996) penggunaan kata "realistik" tidak sekedar menunjukkan adanya suatu koneksi dengan dunia nyata "real world) tetapi lebih mengacu pada fokus PMR. Zulkardi (2002:33) menyatakan bahwa karakteristik PMR yaitu menekankan pada pengajaran bermakna dengan mengaitkannya dalam kehidupan nyata atau kehidupan sehari-hari sehingga dapat dijadikan sebagai sumber atau media dalam proses pembelajaran matematika.

Media merupakan sarana komunikasi (Russell, 2011:7). Menurut Buchori, (2014) media adalah bagian penting dari belajar dalam proses pembelajaran. Pembelajaran dengan E-module merupakan "pembelajaran dengan menggunakan modul yang dalam implementasinya memanfaatkan media elektronik (Wena, 2011:102).

Adapun ciri e-modul adalah dapat menyajikan deskripsi materi pelajaran yang mudah dimengerti, perangkat pembelajaran e-modul memberikan kesempatan kepada siswa untuk melakukan praktik kegiatan pembelajaran(Siagian, 2014:46), hal ini sesuai dengan pendapat Dwi (2010) yang menunjukkan bahwa dengan pengembangan perangkat pembelajaran berbasis masalah pada pembelajaran matematika di SD, salah satunya dengan suplemen modul yang mampu meningkatkan hasil belajar siswa.

Hasil penelitian Suarsana (2013) menunjukkan bahwa melalui penggunaan e-modul didalam pembelajaran, kemampuan berfikir kritis dan hasil belajar siswa mengalami peningkatan yang signifikan dari rata-rata 27,6 (sedang) pada siklus I menjadi 3,14 (tinggi) pada siklus II dan diperoleh nilai e-modul adalah 75,5. Berdasarkan kriteria e-modul berada dalam kategori baik. Bertentangan dengan itu, beberapa peneliti menemukan bahwa bahan ajar berupa e-modul tidak selamanya mampu meningkatkan kemampuan berfikir kritis siswa. Caroline (2013) menyatakan bahwa penggunaan e-modul akan menurunkan hasil belajar siswa jika tidak adanya penyiapan yang matang di dalam lingkungan dan fasilitas belajar siswa, yang meliputi tidak tersedianya sumber daya intruksional media.

Salah satu aplikasi komputer yang dapat digunakan dalam belajar matematika adalah software flipbookmaker. Buchori (2014) berpendapat bahwa Flipbookmaker merupakan perangkat lunak yang dapat digunakan dalam pembuatan bahan ajar secara online dan offline yang mudah dan bisa digunakan untuk semua jenjang pendidikan. Kemudian Pardamean (2013) menyatakan bahwa dengan pengembangan model pendidikan antikorupsi melalui media komik bagi siswa sekolah dasar menunjukkan bahwa dengan media komik mampu sebagai alternatif dalam pemberantasan korupsi di Indonesia sejak dini, artinya media media komik yang dikemas seperti e-modul mampu sebagai alat belajar yang efektif bagi siswa sekolah dasar. Kemudian Sumanto (2010) dengan menggunakan media peragaan gambar dalam pembelajaran kreatif menggambar ilustrasi di kelas IV sekolah dasar, siswa antusias dalam mengikuti peragaan di kelas. Kondisi inilah yang diperlukan oleh siswa sekolah dasar di Indonesia agar antusias mengikuti pembelajaran di kelas. Oleh karena perlu dibuatkan suplemen media berupa e-module yang mampu menampilkan gambar yang menarik dan disesuaikan dengan realitas di lingkungan sekitar siswa yang erat kaitannya dengan materi geometri datar di lingkungan sekitar siswa, misalnya ubin, piring, meja dan lain sebagainya, sehingga siswa mudah memahami materi geometri secara asyik dan menyenangkan.

Dari berbagai permasalahan di atas dapat ditarik tujuan penelitian sebagai berikut: (1) mengembangkan e-modul dengan pendekatan Pendidikan Matematika Realistik (PMR) yang layak digunakan dalam pembelajaran matematika pada materi geometri di sekolah dasar, (2) mendeskripsikan hasil belajar siswa yang menggunakan e-modul dengan pendekatan Pendidikan Matematika Realistik (PMR) lebih baik dari pada pembelajaran konvensional pada materi geometri sekolah dasar. 


\section{METODE}

Penelitian ini merupakan penelitian pengembangan. Menurut Setyosari (2015:115) pengembangan adalah mengembangkan suatu produk tertentu, rancangan atau desain, strategi, pendekatan, atau suatu model. Penelitian ini merupakan pengembangan E-modul dengan pendekatan PMR yang mengacu pada model 4-D dengan beberapa modifikasi, (Hamdani, 2011: 27). Desain pembelajaran model 4-D terdiri atas empat tahap utama, yaitu Define (pendefinisian), Design (perancangan), Develop (pengembangan), dan Disseminate (penyebaran. Pada pengembangan ini peneliti tidak melakukan tahap disseminate, karena waktu dan target penelitian terbatas sehingga peneliti hanya melakukan sampai pada uji terbatas. Subyek penelitian dalam uji coba terbatas adalah berasal dari kelas IV siswa SDN Pedurungan tengah 01 Semarang. Sebagai kelas Eksperimen diperoleh dari kelas A dan kelas B sebagai kelas Kontrol.

\section{Prosedur Pengembangan}

Prosedur pengembangan e-modul dalam penelitian ini mengacu pada pengembangan 4-D. Pada desain pembelajaran model 4-D, peneliti mengambil langkah sampai tahap ketiga yaitu develop (pengembangan). Secara garis besar, ketiga tahap langkah tersebut sebagai berikut (Hamdani, 2011:27-30).

Tahap pendefinisian (define), tujuannya adalah menetapkan dan mendefinisikan syarat-syarat pembelajaran diawali dengan analisis tujuan dari batasan materi yang dikembangkan perangkatnya. tahap ini meliputi lima langkah pokok, yaitu analisis awal dan akhir, analisis siswa, analisis materi, analisis tugas, dan perumusan tujuan pembelajaran.

Tahap perencanaan (design), tujuan tahap ini adalah menyiapkan prototipe perangkatpembelajaran. Tahap pengembangan (develop) tujuannya adalah menghasilkan perangkat pembelajaran yang sudah direvisi berdasarkan masukan dari pakar.

\section{Teknik Pengumpulan Data}

Adapun teknik pengumpulan data adalah sebagai berikut. Istrumen yang digunakan dalam validasi ahli ini adalah lembar validasi. Adapun lembar validasi yang diperlukan adalah sebagai berikut. Pertama, lembar validasi ahli materi merupakan lembar yang ditujukan kepada ahli materi pembelajaran matematika. Dalam hal ini ahli materi adalah dosen Universitas PGRI Semarang dan guru SD. Ahli tersebut akan memvalidasi tentang materi yang ada pada produk yang hasilnya berupa isi materi dalam e-modul. Kedua, lembar validasi ahli media merupakan lembar yang ditujukan kepada ahli media. Ahli media menilai pada tampilan produk, konsistensi e-modul, format e-modul dan daya tarik e-modul. Ketiga, lembar kuesioner (Angket) merupakan teknik pengumpulan data yang dilakukan dengan cara memberi seperangkat pertanyaan atau pernyataan tertulis kepada responden untuk dijawabnya.

Teknik analisis data dengan acuan yang diadaptasi dengan menggunakan skala Likert yang nantinya akan dideskripsikan secara kualitatif. Menurut Arikunto (2013:195) skala Likert disusun dalam bentuk suatu pernyataan dan diikuti oleh lima respon yang menunjukan tingkatan. Pada penelitian ini skala yang digunakan adalah: Sangat baik (SB) dengan skor 5, Baik (B) dengan skor 4, Cukup baik (CB) dengan skor 3, Kurang baik (KB) dengan skor 2, Tidak baik (TB) dengan skor 1. Dalam menganalisis data dari kuisioner (angket) dilakukan langkah-langkah sebagaimana yang telah dijelaskan Arikunto (2013:265) dalam analisis deskriptif kualitatif sebagai berikut. Langkah1: peneliti menjumlahkan tanda centang yang ada pada setiap kolom untuk kemudian dicari besarnya persentase untuk masing-masing kategori. Langkah 2: menjumlahkan banyaknya tanda centang pada setiap kolom yang terdapat matriks alat bantu. Jumlah tersebut dibandingkan dengan jumlah seluruh uraian materi kemudian dicari persentasenya. Langkah 3: menuliskan besarnya persentase dalam setiap kolom.

\section{HASIL DAN PEMBAHASAN}

Dalam penelitian research development ini dihasilkan sebuah media e-modul dengan pendekatan matematika realistik pada materi bangun datar segiempat dengan mengikuti prosedur pengembangan 4D sebagai berikut.

\section{Define (Pendefinisian)}

Adapun persiapan-persiapan yang dilakukan sebelum penelitian yang merupakan tahap define pada prosedur pengembangan $4 \mathrm{D}$ adalah sebagai berikut. Melakukan observasi dan konsultasi 
dengan Kepala Sekolah, Wakil Kepala Sekolah bidang Kurikulum dan guru mata pelajaran matematika kelas IV SDN Pedurungan Tengah 01 Semarang. Dimana dalam observasi proses pembelajaran, peneliti mengidentifikasi bahwa terdapat kekurangan dalam proses pembelajaran.

\section{Design (Perencanaan)}

Pada tahap ini merupakan tahap design pada prosedur pengembangan 4-D. Dalam tahap desain produk ini peneliti membuat rancangan desain untuk mengembangkan e-modul dengan pendekatan PMR pada materi geometri yang akan digunakan sebagai media pembelajaran. Hal-hal yang diperlukan dalam menyusun produk tersebut adalah menetapkan mata pelajaran yang akan dikembangkan yaitu mata pelajaran matematika khususnya pada materi geometri datar yaitu keliling dan luas bangun datar segiempat untuk siswa kelas IV Semester gasal dengan Standar Kompetensi yaitu: Memahami konsep segiempat dan segitiga serta menentukan ukurannya.

Tahap selanjutnya adalah pengumpulan data bahan atau materi pelajaran yang diperlukan untuk pembuatan produk sesuai materi pokok (subtansi mata pelajaran matematika), aspek pendukung seperti gambar dan lain-lain. Pengumpulan materi pokok dilakukan dengan menggunakan sumbersumber atau buku-buku mata pelajaran. Sedangkan pengumpulan gambar diperoleh melalui download melalui internet. Tahap terakhir adalah pembuatan produk yaitu e-modul dengan pendekatan PMR

\section{Develop (Pengembangan)}

Pada tahap ini dilakukanlah validasi ahli (evaluasi formatif) pada produk yang telah dibuat. Produk media pembelajaran berupa e-modul dengan pendekatan PMR pada materi geometri datar yaitu keliling dan luas bangun datar segiempat dalam pembelajaran matematika sebagai hasil dari pengembangan ini diuji tingkat validitas dan keefektifannya. Tingkat validitas media pembelajaran diketahui melalui hasil analisis kegiatan uji coba.

\section{Hasil Validasi Media}

Analisis ahli media ditinjau dari aspek: (1) aspek umum, (2) penyajian pembelajaran, (3) kelayakan bahasa, dan (4) kelayakan kegrafikan. Berdasarkan perhitungan, diketahui persentase $=85,2 \%$, setelah dikonversikan dengan tabel konversi skala, persentase tingkat pencapaian $85,2 \%$ berada pada kualifikasi sangat baik sehingga media pembelajaran layak diuji cobakan dengan memerlukan revisi sedikit.

Komentar secara umum dari validator 1 adalah media e-modul layak diujicobakan di lapangan tanpa adanya revisi. Tetapi validator 2 memerlukan revisi adapun beberapa revisi yang dilakukan dapat dilihat pada tabel 1 .

Hasil validasi ini sangat sesuai dengan pendapat Saadati, dkk (2014), tentang pentingnya TIK dalam pembelajaran matematika di kelas, mereka juga merasa nyaman dan percaya diri dengan teknologi, mereka tidak memiliki pengalaman yang lebih dalam penggunaan teknologi di kelas matematika sebelumnya. Temuan ini mendukung penelitian lain yang menunjukkan potensi TIK dalam memfasilitasi belajar siswa, kemudian diperkuat oleh Lestariningsih, dkk (2015) yang terkait pembelajaran geometri di sekolah dasar bahwa desain pembelajaran debit menggunakan debit Lumpur Lapindo berdasarkan pendekatan PMRI dapat mendukung pemahaman siswa dalam pembelajaran konsep debit. Dari penilaian ahli media sangat jelas bahwa media e-modul geometri di sekolah dasar ini layak digunakan dalam pembelajaran di sekolah.

\section{Hasil Validasi Materi}

Analisis ahli materi ditinjau dari: (1) aspek umum, (2) substansi materi, dan (3) desain pembelajaran. Validasi dilakukan oleh 2 ahli yang berkompeten pada bidangnya.

Berdasarkan perhitungan, diketahui persentase $=89,2 \%$, setelah dikonversikan dengan tabel konversi skala, persentase tingkat pencapaian $89,2 \%$ berada pada kualifikasi sangat baik sehingga media pembelajaran layak diuji cobakan. Sedangkan komentar secara umum dari validator 1 adalah media layak diujicobakan di lapangan dengan sedikit revisi. Tetapi validator 2 layak diujicobakan tanpa adanya revisi. Adapun revisi tersebut dapat dilihat pada tabel 2 .

Berdasarkanvalidasiahlimateritentang cakupan materi matematika SD dengan content matematika realistic dikuatkan dengan pendapat Hongki dkk (2014) yang menunjukkan profil kognitif guru SD yang belum dan telah mengikuti workshop PMRI, serta yang belum dan telah mempelajari sumber belajar tentang filosofi, prinsip, dan karakteristik dari 
Tabel 1. Revisi Desain Ahli Media Berdasarkan Validator 2

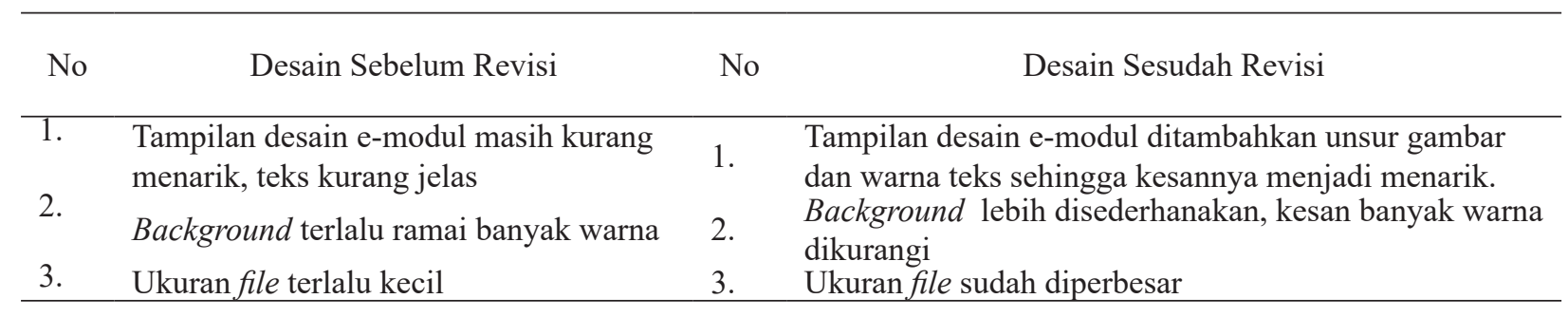

Tabel 2. Revisi Desain Ahli Materi Berdasarkan Validator 1

\begin{tabular}{llll}
\hline No & Desain Sebelum Revisi & No & Desain Sebelum Revisi \\
\hline 1. & $\begin{array}{l}\text { Contoh soal perlu diperbanyak lagi tanpa } \\
\text { bervariasi }\end{array}$ & 1. & $\begin{array}{l}\text { Contoh soal sudah diperbanyak dan dibuat } \\
\text { bervariasi }\end{array}$ \\
2. & Perkuat kajian teori tentang PMR & 2. & $\begin{array}{l}\text { Kajian teori dalam contoh soal } \\
\text { dibuat lebih realistik }\end{array}$ \\
3. & Format penulisan ada kesalahan & 3. & Format penulisan sudah diperbaiki \\
\hline
\end{tabular}

pendekatan matematika realistik. Dari hasil risetnya menunjukkan bahwa guru dan siswa yang telah diberi pengarahan tentang prinsip dan karakteristik matematika realistik akan lebih memahami inti dari pendekatan realistic. Hal ini sangat sesuai dengan pendapat ahli materi bahwa produk e-modul ini didalamnya lengkap dengan contoh-contoh konkret yang ada dilingkungan sekitar siswa-siswa anak sekolah dasar. Sehingga prinsip dan karakteristik matematika realistik mudah dimengerti siswa dalam implementasi materi bangun datar terutama luas dan keliling bangun datar segi empat dalam kehidupan sehari-hari.

\section{Hasil Tanggapan Siswa}

Produk yang diujicobakan berupa produk e-modul dengan pendekatan matematika realistik dengan menggunakan software flipbookmaker. E-modul ini ditanggapi oleh 34 siswa yang berasal dari kelas IVA. Siswa menanggapi e-modul ini dengan cara mengisi angket yang diberikan peneliti untuk diisi siswa. Analisis tanggapan siswa ditinjau dari aspek kelayakan penyajian, materi, contoh soal dan latihan soal, serta aspek keingintahuan siswa. Berdasarkan perhitungan, didapatkan persentase sebesar $85,2 \%$. Setelah dikonversikan, persentase tersebut berada pada kualifikasi sangat baik sehingga e-modul layak digunakan sebagai media pembelajaran pada materi keliling dan luas bangun datar segiempat.

Berkaitan dengan tanggapan siswa terhadap produk e-modul matematika materi geometri untuk siswa sekolah dasar dengan pendekatan matematika realistik mendapatkan respon yang sangat baik. Hal ini diperkuat oleh Achmad, dkk (2014) yang menunjukkan bahwa siswa dapat memahami konsep penyelesaian persamaan kuadrat dengan cara melengkapkan kuadrat sempurna melalui metode nä̈ve geometry, yang diinterpretasikan sebagai manipulasi bentuk persegi panjang menjadi bentuk persegi. Pada akhir pertemuan, siswa juga diarahkan untuk menemukan rumus bentuk umum penyelesaian persamaan kuadrat. Dalam hal ini siswa sekolah dasar yang dikenai e-modul juga memilih model persegi dan persegi panjang yang diidentifikasi kesamaan kedua bangun datar tersebut, sehingga siswa tertantang untuk menemukan luas dan keliling dari bangun datar segiempat secara cermat.

\section{Hasil Belajar Siswa}

Adapun analisis yang digunakan untuk menguji apakah rata-rata hasil belajar kelompok eksperimen lebih baik dari kelompok kontrol dilakukan uji t satu pihak kanan. Dari hasil perhitungan yang diperoleh hasil $t_{\text {hitung }}=6,381$. Hasil tersebut kemudian dikonsultasikan dengan $\mathrm{t}_{\text {tabel }}=$ 1,669. Karena $\mathrm{t}_{\text {hitung }}>\mathrm{t}_{\text {tabel }}$ yaitu 6,381 $>1,669$ maka Ho ditolak, dengan demikian bahwa hasil belajar peserta didik yang menggunakan e-modul dengan pendekatan pendidikan matematika realistik lebih baik dari pembelajaran konvensional.

Adapun siswa dikatakan tuntas secara individu jika telah memperoleh $\geq \mathrm{KKM}$. Kriteria 
Ketuntasan Minimal (KKM) yang dipakai adalah 75. Berdasarkan hasil perhitungan ketuntasan belajar individu untuk kelas eksperimen terdapat 31 siswa yang tuntas dari 34 siswa. Sedangkan untuk kelas kontrol terdapat 15 siswa yang tuntas dari 34 siswa. Dan Suatu kelas dikatakan tuntas secara klasikal jika KKM dikelas tersebut terdapat $\geq 75 \%$ siswa. Berdasarkan persentase ketuntasan belajar klasikal untuk kelas eksperimen sebesar 91,18\% dan untuk kelas kontrol sebesar 44,12\%. Untuk rata-rata kelas eksperimen sebesar 84,147 dan ratarata kelas kontrol sebesar 68,589. Jadi, rata-rata kelas eksperimen lebih besar dari pada rata-rata kelas kontrol.

Hasil belajar siswa mengalami peningkatan dengan adanya media yang sesuai siswa kebutuhan siswa, hal ini didukung penelitian Umi dkk (2015) yang menunjukkan bahwa dengan menggunakan set model dan permainan remibilbul dalampembelajaran penjumlahan bilangan bulat di kelas IV SD, dengan ditunjukkan aktivitas mencatat transaksi keuangan dalam keping dua warna dan permainan remi bilbul dapat memunculkan strategi berpikir siswa dalam menjumlahkan bilangan bulat, artinya dengan media pembelajaran mampu meningkatkan aktivitas belajar siswa, dikuatkan lagi oleh Muhammad (2015) yang mampu mengembangkan media bahan ajar cerita fiksi berbasis wacana budaya di sekolah dasar, artinya bahwa media mampu menarik siswa dalam semua mata pelajaran, tidak hanya mata pelajaran matematika saja.

\section{SIMPULAN DAN SARAN}

\section{Simpulan}

Produk yang dihasilkan dalam penelitian ini adalah media pembelajaran berupa e-modul dengan pendekatan pendidikan matematika realistik (PMR) pada materi geometri datar khususnya materi keliling dan luas bangun datar segiempat.

Berdasarkan penilaian dan tanggapan dari ahli media, ahli materi dan hasil respon siswa, secara umum media pembelajaran ini mempunyai keunggulan dibandingkan dengan media pembelajaran konvensional. yang termasuk dalam kualifikasi sangat baik, sehingga media pembelajaran ini layak digunakan dalam pembelajaran matematika khususnya materi geometri datar.

Uji coba produk dilakukan dikelas eksperimen di SDN Pedurungan Tengah 01 Semarang yang terdiri dari 34 siswa. e-modul ini memiliki tampilan fisik yang baik dan menarik. Daftar isi dan peta konsep membantu memahami materi. Memiliki tingkat kejelasan yang baik antara petunjuk penggunaan e-modul, tujuan pembelajaran, paparan materi, rangkuman, tugas, tes formatif, lembar kerja dan evaluasi dalam e-modul. Sehingga uraian materi, contoh, tugas, tes formatif, lembar kerja, dan evaluasi mudah dipahami oleh siswa. Hal tersebut menyatakan bahwa media pembelajaran ini sangat menarik dan digunakan sebagai media pembelajaran yang mendukung dalam pemecahan masalah pembelajaran di kelas.

Dalam penggunaan e-modul geometri ini, anakanak SD pedurungan tengah 01 semarang sangat menarik dan antusias karena semua materi dikemas secara menarik dan dikaitkan uraian materi dan contoh-contoh soalnya dengan kehidupan seharihari yang realistik, sehingga siswa merasa tahu akan kegunaan materi yang dipelajari dengan aplikasinya dalam kehidupan sehari-hari.

\section{Saran}

Sebaiknya penggunaan media e-modul lebih diperdalam konten materi geometri datarnya, sehingga siswa lebih menguasai secara konsep materi dengan benar, kemudian penggunaan media e-module dengan flipbookmaker lebih ditekankan desainnya sesuai anak-anak SD sehingga mempermudah belajar siswa.

\section{DAFTAR RUJUKAN}

Achmad, D.F, Ratu Ilma, I. P, \& Darmawijoyo. 2014. Building Students' Understanding Of Quadratic Equation Concept Using Naïve Geometry, IndoMS-JME. 5(2):192-202

Buchori, A. 2014. "Development of Matiklopedia Based Character Building in Yunior High School". International seminar on innovation in mathematics and mathematics education. diakses November 2014. Yogyakarta state university.

Caroline, A \& Moses. 2013. "Challenges Facing Teachers In Preparation And Utilization Of Instructional Media In Teaching Kiswahili In Selected Secondary Schools In Kenya". Journal of advanced research; Vol. 1 Issue 3. Diakses Mei 2013. Kenya: University of science and technology. 
Dickinson, P \& Sue, H. 2012. Using Realistic Mathematics Education in UK Classrooms. United Kingdom.

Dwi, P.U. 2010. Pengembangan Perangkat Pembelajaran Berbasis Masalah pada Pembelajaran Matematika di SD, Jurnal Sekolah Dasar. 19(1).

Farzaneh, S. Rohani, A.T, \& Ahmad fauzi. 2014. Utilization of Information and Communication Technologies in Mathematics Learning, IndoMS-JME. 5(2):138-147

Freudenthal, Hans. 2002. Revisiting Mathematics Education. University of Utrecht: Kluwer Academic Publishers.

Hamdani, 2011. Strategi Belajar Mengajar. Bandung: Pustaka Setia.

Heuvel-Panhuizen, V.d 1996. Assessment And Realistic Mathematics Education. Utrech: Freudenthal institute. Netherlands.

Julie, H., Suwarsono, \& Juniati, D.2014 , Understanding Profile From The Philosophy, Principles, And Characteristics Of RME, IndoMS-JME. 5(2):148-159

Lestariningsih., Anwar, M., \& Mulyanto, A.S. 2015. Investigating The Act Of Design In Discharge Concept Using PMRI. IndoMS-JME. 6(2):5059

Muhammad, R.T \& Sultan, J .2015. Pengembangan Bahan Ajar Cerita Fiksi Berbasis Wacana Budaya di Sekolah Dasar. Jurnal Pendidikan dan Pembelajaran. 22(2):169-175.

Pardamean, D \& Malik, A.2013. Pengembangan Model Pendidikan Antikorupsi Melalui Media Komik bagi Siswa Sekolah Dasar. Jurnal Sekolah Dasar. 22(1).

Russell, James dkk. 2011. Intructional Technology and Media For Learning. Jakarta: Kencana

Saglam, H.I. 2011. "An Investigation On Teaching Materials Used In Social Studies Lesson" Journal of Educational Technology. 10(1):478485.
Setyosari, P. 2015. Metode Penelitian Pendidikan Dan Pengembangan. Jakarta: Kencana.

Siagian, S. 2014. "Development of Basic Electronic Instructional Module and Trainer". Journal of Computer Science and Information Technology 2(3): $156-168$

Suarsana. 2013 "Pengembangan E-Modul Berorientasi Pemcahan Masalah Untuk Meningkatkan Keterampilan Berfikir Kritis Mahasiswa". Jurnal. 2(2):89-101.

Sumanto. 2010. Penggunaan Media Peragaan Gambar dalam Pembelajaran Kreatif Menggambar Ilustrasi di kelas IV Sekolah Dasar. Jurnal Sekolah Dasar. 19(1).

Susana, D \& Zubir, A. 2014. "Penerapan Pendekatan Pendidikan Matematika Realistic (PMR) Terhadap Kemampuan Pemecahan Masalah Matematika Siswa SMP Negeri 1 Sungai Penuh". Jurnal Penelitian Universitas Jambi. 17(1):78-89

Umi, P.L., Ratu, I.I.P., \& Hartono, Y. 2015. Penggunaan Set Model Dan Permainan Remi Bilbul Dalam Pembelajaran Penjumlahan Bilangan Bulat Di Kelas IV SD, Jurnal Sekolah Dasar. 24(2):187-198.

Wayan. 2013. "Pengembangan Modul Matematika Realistik Disertai Asesmen Otentik Untuk Meningkatkan Hasil Belajar Matematika Peserta Didik Kelas X". Journal Pasca Sarjana. 3:71-83.

Wena, M. 2013. "Pengembangan E-Modul Bermuatan Model Perubahan Konseptual Dalam Pembelajaran Fisika Di SMA”. Jurnal Santi Aji Pendidikan. 1(1):51-64

Zulkardi. 2002. Developing A Learning Environment On Realistic Mathematics Education For Indonesian Student Teachers. Thesis University of Twente. 